\title{
PENERAPAN MODEL PEMBELAJARAN INKUIRI TERBIMBING DALAM UPAYA MENGURANGI MISKONSEPSI PESERTA DIDIK MATERI REAKSI REDOKS
}

\author{
The Application of a Guided Inquiry Model in an Effort to Reduce \\ Students' Misconceptions in the Redox Reaction Material
}

Nurhidayah*, Bambang Suharto, Leny

Program Studi Pendidikan Kimia FKIP Universitas Lambung Mangkurat, Jl. Brigjend. H. Hasan Basry Banjarmasin 70123 Kalimantan Selatan Indonesia *email: nurhidayahkimia14@gmail.com

\begin{abstract}
Abstrak. Telah dilakukan penelitan tindakan kelas tentang upaya mengurangi miskonsepsi peserta didik. Tujuan penelitian ini untuk mengetahui: (1) aktivitas guru; (2) aktivitas peserta didik; (3) penurunan miskonsepsi; (4) pemahaman konsep peserta didik (5) respon peserta didik terhadap model inkuiri terbimbing materi reaksi redoks. Rancangan penelitian tindakan kelas (PTK) dilakukan secara bersiklus. Peserta didik kelas X MIPA 1 SMAN 1 Gambut dengan jumlah 35 orang sebagai subjek penelitian. Instrumen penelitian yang digunakan yaitu tes dan non tes. Teknik analisis data menggunakan analisis kuantitatif deskriptif dan kualitatif. Berdasarkan hasil peneltian dapat disimpulkan terjadi (1) Aktivitas guru kategori baik meningkat menjadi sangat baik; (2) terjadi peningkatan aktivitas peserta didik kategori aktif pada siklus I menjadi sangat aktif pada siklus II; (3) terjadi penurunan miskonsepsi peserta didik; (4) terjadi peningkatan pemahaman konsep sebesar; (5) peserta didik memberikan respon yang positif pada model inkuiri terbimbing.
\end{abstract}

Kata kunci: model inkuiri terbimbing, miskonsepsi, reaksi redoks

\begin{abstract}
Classroom action research has been carried out about efforts to reduce students' misconceptions. This research to find out (1) teacher activity (2) Student activity (3) deacrese misconception (4) understanding of students' concepts ; (5) response of students to redox reaction material. Classroom action research (CAR) design is carried out cyclically. The research used a research subject was 35 students of class X MIPA 1, SMAN 1 Gambut. The research instrument was in the form of tests and non-tests. use a class action plan (PTK) on a cycle basis. The data analysis technique uses descriptive and qualitative quantitative analysis. The results of the research show that it happened. (1) the increase in teacher activity from the good category in the first cycle became very good in cycle II (2) there was an increase in the activity of students from the active category in the first cycle to be very active in cycle II;(3) there was a decrease in misconception (4) there was an increase in concept understanding (5) Students give a positive response to learning using a guided inquiry model.
\end{abstract}

Keywords: guided inquiry models, misconception, redoxs reaction.

\section{PENDAHULUAN}

Tujuan pembelajaran kimia yang harus dicapai peserta didik adalah peserta didik mampu menguasai konsep-konsep kimia, mengaitkan dengan materi kimia yang telah dipelajarinya, kemudian mampu mengaitkan dengan materi yang akan dipelajarinya. Realita yang terjadi di sekolah adalah mata pelajaran kimia di anggap sulit oleh peserta didik SMA, sehingga mereka tidak berhasil mencapai nilai

Copyright $\odot$ JCAE-Jurnal Tugas Akhir Mahasiswa, e-ISSN 2613-9782

Program Studi Pendidikan Kimia FKIP Universitas Lambung Mangkurat 
ketuntasan minimal serta masih kesulitan menjelaskan konsep-konsep dalam belajar kimia (Kusumawati, Enawaty, \& Lestari, 2014). Kesalahan peserta didik memahami konsep dalam pembelajaran menjadi masalah yang perlu secepatnya ditemukan solusinya. Konsep yang tidak selaras dengan yang diakui para ahli disebut miskonsepsi (Suparno, 2013).

Filsafat konstruktivisme menjelaskan terjadinya miskonsepsi karena pengetahuan yang dibangun peserta didik berdasarkan lingkungan dan bahan yang dipelajari (Suparno, 2013). Menurut Suparno (2013) ada lima hal yang menjadi penyebab miskonsepsi yaitu guru, peserta didik, metode mengajar,buku teks, dan konteks pembelajaran. Selain dari beberapa faktor tersebut hal yang menjadi sebab terjadinya miskonsepsi seperti yang dikemukakan Rusmansyah (2002) juga karena pada umumnya peserta didik tidak membangun pemahaman terhadap konsep-konsep dan cenderung belajar dengan menghafal. Peserta didik tidak terbiasa menggali kata kunci yang diperlukan untuk memahami konsep-konsep tersebut, sehingga peserta didik tidak dapat membangun konsep yang fundamental pada awal mereka belajar kimia (Widiyowati, 2014).

Menurut Barke (2012) salah satu konsep kimia yang mengalami kesalahpahaman yaitu konsep reaksi redoks. Reaksi redoks ini menuntut peserta didik memiliki kemampuan yang meliputi kemampuan mengidentifikasi jenis suatu reaksi (oksidasi, reduksi, atau oksidasi-reduksi) bila diketahui persamaan reaksinya, kemampuan menentukan bilangan oksidasi suatu unsur dalam suatu senyawa netral dan ion poliatom, kemampuan menentukan zat yang bertindak sebagai oksidator atau reduktor dan menentukan nama senyawa berdasarkan IUPAC. Model pembelajaran inkuiri terbimbing terbukti dapat mengurangi miskonsepsi peserta didik.

\section{METODE PENELITIAN}

Jenis penelitian ini adalah tindakan kelas (Action Research). Dilaksanakan dalam dua siklus, dengan empat tahapan kegiatan pada setiap siklu: (1) perencanaan, (2) pelaksanaan tindakan, (3) Observasi dan evaluasi (4) analisis dan refleksi. Acuan untuk memutuskan siklus berakhir apabila indikator keberhasilan dalam penelitian telah tercapai dan masalah yang menjadi fokus dalam penelitian dapat dipecahkan dengan baik.

Penelitian dilakukan di SMAN 1 Gambut beralamat Jl. A. Yani Km. 14.800, Kayu Bawang, Banjar, Kalimantan Selatan. Seluruh peserta didik kelas X MIPA 1 SMAN 1 Gambut, 24 orang peserta didik perempuan dan 11 orang peserta didik lakilaki menjadi subjek penelitian ini.

Instrumen yang digunakan adalah non tes dan tes. Tes yang digunakan sebagai instrumen adalah three tier multiple choice berjumlah 15 buah yang diadaptasi dari two tier multiple choice yang telah digunakan Jauhariansyah (2014) untuk mengungkap pemahaman konsep peserta didik pada materi reaksi redoks dan larutan elektrolit. Peneliti menambahkan tingkatan pertanyaan berupa tingkat keyakinan peserta didik dalam menjawab pertanyaan. Instrumen meliputi perkembangan konsep reaksi redoks, menentukan bilangan oksidasi, menetukan reduktor dan oksidator dan menentukan nama senyawa berdasarkan IUPAC. Sebelum dilaksanakan penelitian dilakukan validasi ulang dengan menggunakan statistik yang diusulkan Aiken's (1985) dengan rata-rata nilai V sebesar 0,94 yang berarti instruman telah valid layak digunakan. Sedangakan untuk tingkat reliabilitas instrumen dihitung dengan rumus KR-20 dan didapatkan koefisien reliabilitas sebesar 0,84 termasuk dalam kategori tinggi yang berarti instrumen layak digunakan.

Analisis data menggunakan analisis data kualitatif berupa data aktivitas guru, aktivitas dan respon peserta didik, sedangkan data kuantitatif berupa data miskonsepsi 
dan pemahaman peserta didik. Keterlaksanaan observasi aktivitas peserta didik menggunakan skala rentang 1-5, skor maksimal 54,6 - 65 dengan kategori sangat aktif. Observasi aktivitas guru menggunakan skala rentang 1-5, skor maksimal 54,6 65 dengan kategori sangat baik dan respon peserta didik menggunakan skala rentang $1-5$, skor maksimal 42 - 50 dengan kategori sangat baik.

\section{HASIL PENELITIAN DAN PEMBAHASAN}

Hasil penelitian terdiri atas data kualitatif berupa data hasil observasi aktifitas peserta didik, observasi aktifitas guru dan data hasil respon peserta didik, sedangkan data kuantitatif berupa data hasil tes miskonsepsi dan pemahaman konsep peserta didik.

\section{Aktivitas peserta didik}

Skor aktivitas peserta didik dapat dilihat pada Gambar 1.

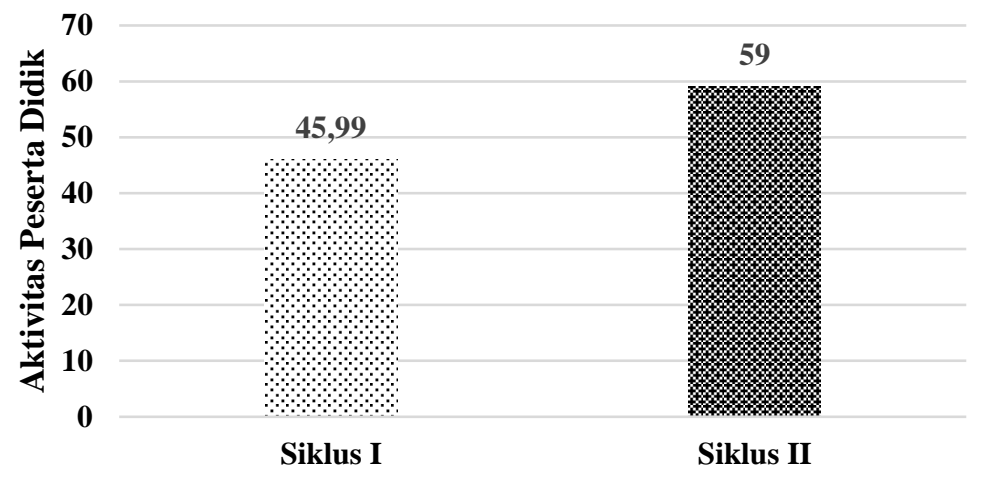

Gambar 1. Skor aktivitas peserta didik siklus I dan II

\section{Aktivitas guru}

Peningkatan skor aktivitas guru dapat dilihat pada Gambar 2.

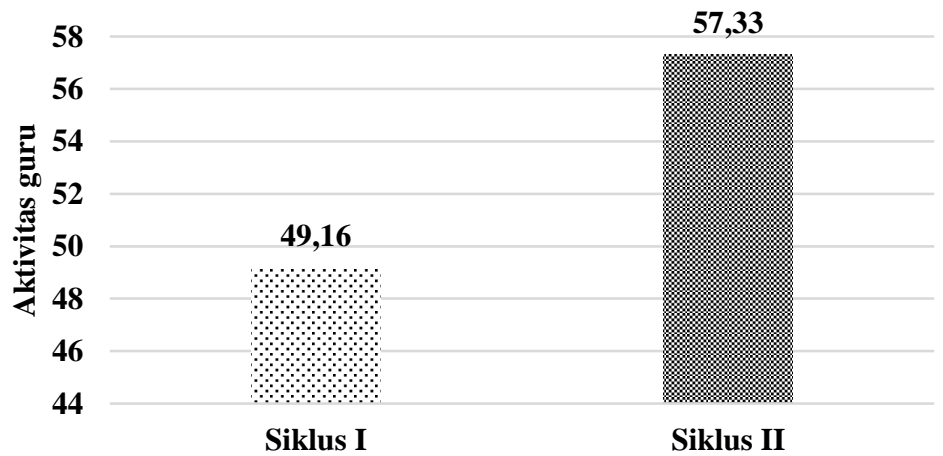

Gambar 2. Skor aktivitas guru

Gambar 2 tersebut dapat diketahui bahwa terjadi peningkatan yang sangat baik terhadap pelaksanaan pembelajaran pada siklus II. Skor hasil observasi aktivitas guru pada siklus I yaitu sebesar 49,16 dengan kategori baik meningkat pada siklus II menjadi 57,33 dengan kategori sangat baik. 


\section{Respon peserta didik}

Respon peserta didik terhadap pembelajaran dengan model inkuiri terbimbing memiliki nilai rata-rata yaitu 39,82 dengan kategori baik. Skor respon peserta didik dapat dilihat pada Gambar 3.

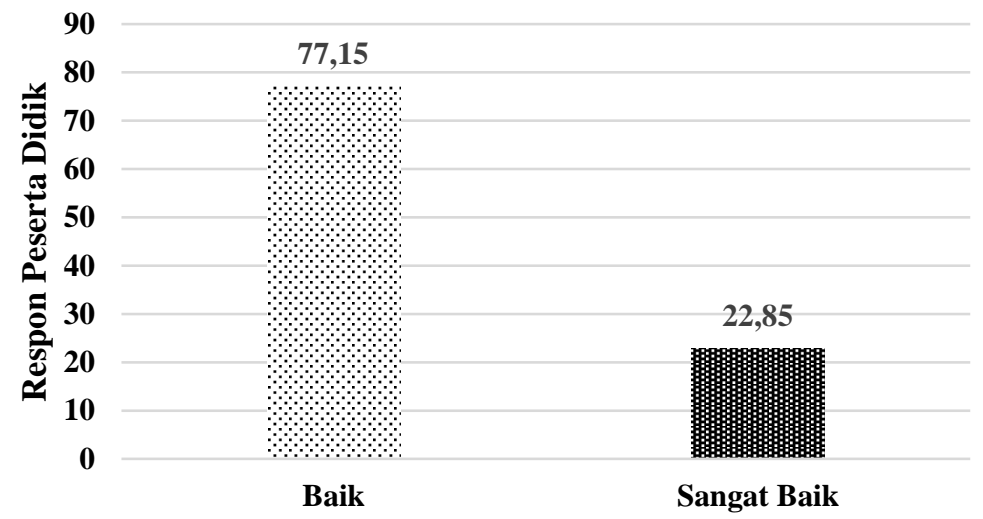

Gambar 3. Skor respon peserta didik

Berdasarakan Gambar 3 tersebut, skor dengan kriteria paling tinggi yaitu pada kategori baik sebesar 77,14. peserta didik memberikan respon positif terhadap pembelajaran reaksi redoks dengan model inkuiri terbimbing. Respon postif terlihat dari banyaknya yang peserta didik yang memberikan respon setuju. Selain itu respon positif peserta didik juga terlihat bahwa pembelajaran dengan menggunakan model pembelajaran inkuiri terbimbing mebuat peserta didik menjadi lebih tertarik, termotivasi, bersemangat mengikuti pembelajaran serta memiliki kemauan yang tinggi untuk mengikuti pembelajaran, lebih mudah memahami materi reaksi redoks serta melalui kegiatan penyelidikan peserta didik dapat menemukan konsep yang dipelajari.

\section{Miskonsepsi peserta didik}

Observasi awal dilakukan dengan memberikan serangkaian soal three tier multiple choice sebagai alat pendeteksi miskonsepsi peserta didik. persentase hasil jawaban tes awal peserta didik dapat dilihat pada Gambar 4.

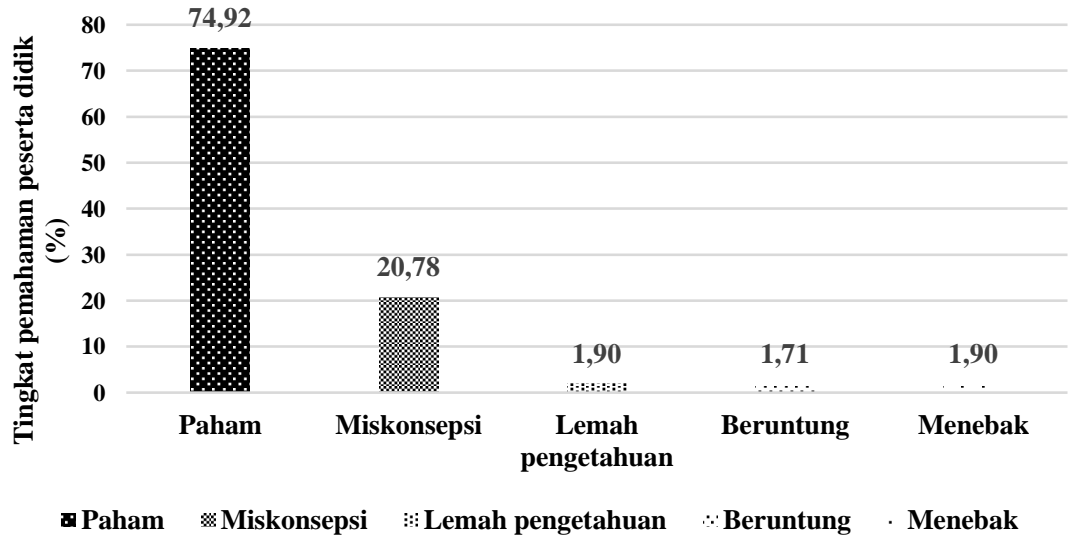

Gambar 4. Skor respon peserta didik terhadap pembelajaran model inkuiri terbimbing. 
a. Indikator 1

Miskonsepsi indikator 1 termasuk dalam kategori sedang. Miskonsepsi peserta didik pada indikator 1 subkonsep perkembangan reaksi redoks yaitu dalam memilih mana yang merupakan reaksi berdasarkan penggabungan dan pelepasan oksigen dan mana yang bukan. Miskonsepsi diidentifikasi dengan butir soal nomor 1 dan 2 dengan pola jawaban terbanyak adalah benar, salah yakin dan salah benar yakin.

\section{b. Indikator 2}

Miskonsepsi indikator 2 termasuk dalam miskonsepsi kategori rendah. Miskonsepsi peserta didik subkonsep menentukan bilangan oksidasi diidentifikasi dengan butir soal nomor 3,4 dan 5. Miskonsepsi hanya terjadi pada nomor 3 dan 5, dengan pola jawaban terbanyak adalah benar, salah, yakin, sedangkan untuk soal nomor 5 peserta didik mengalami miskonsepsi hanya sebesar $11,43 \%$.

\section{c. Indikator 3}

Miskonsepsi indikator 3 termausk dalam miskonsepsi kategori rendah. Miskonsepsi peserta didik subkonsep menentukan reduktor dan oksidator diidentifikasi dengan butir soal nomor 6,7,8,9 dan 10. Persentase miskonsepsi peserta didik tiap butir soal yaitu persentase miskonsepsi nomor 6 sebesar 28,57\%, nomor 7 sebesar $11,43 \%$, nomor 8 sebesar $17,14 \%$, nomor 9 sebesar $34,29 \%$ dan nomor 10 sebesar $48,57 \%$. Miskonsepsi pada indikator 3 ini dikarenakan peserta didik keliru dalam menentukan spesi mana yang bertindak sebagai reduktor maupun oksidator. Peserta didik beranggapan reduktor adalah spesi yang mengalami penurunan bilangan oksidasi atau yang mengalami reduksi, begitupun sebaliknya.

\section{d. Indikator 4}

Miskonsepsi indikator 4 termasuk miskonsepsi kategori rendah. Miskonsepsi peserta didik subkonsep tata nama senyawa redoks berdasarkan IUPAC diidentifikasi dengan butir soal nomor 11,12,13,14 dan 15. Persentase miskonsepsi pada soal nomor 11 sebesar 2,86\%, soal nomor 2 sebesar $11,43 \%$, soal nomor 13 sebesar $28,57 \%$, soal nomor 14 sebesar $2,86 \%$ dan soal nomor 15 sebesar $20,00 \%$

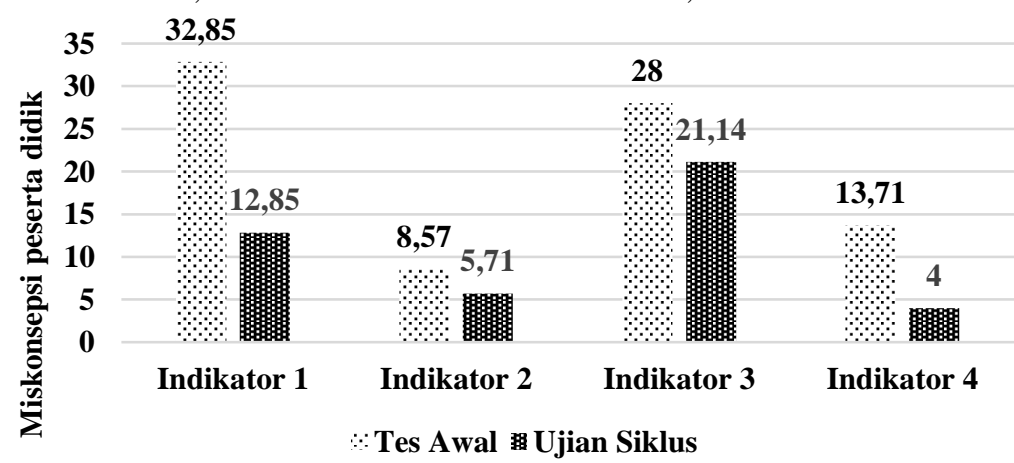

Gambar 5. Perbandingan persentase tes awal dengan tiap indikator

Hasil pembelajaran siklus I miskonsepsi peserta didik pada indikator 1 mengalami penurunan sebesar $25,72 \%$, sedangkan pada indikator 2 peserta didik mengalami penurunan miskonsepsi sebesar 16,2\%. dan indikator 3 peserta didik mengalami penurunan miskonsepsi sebesar $2,86 \%$ dari tes awal. terdapat $28,56 \%$ peserta didik yang tidak memenuhi standar kriteri ketuntasan minimal (KKM). Hasil pembelajaran siklus II miskonsepsi peserta didik berkurang dari $13,71 \%$ menjadi $4,00 \%$. terjadi penurunan miskonsepsi sebesar 9,71\% dan terjadi peningkatan pemahaman peserta didik dari $88,57 \%$ menjadi $94,85 \%$. Terjadi peningkatan 
pemahaman peserta didik sebesar $6,28 \%$. Seluruh peserta didik memenuhi standar KKM.

Berdasarkan penelitian Ngertini, Sadia \& Yudana (2013) bahwa penerapan model inkuiri terbimbing memberikan pencapaian pemahaman konsep yang optimal. Sejalan dengan penelitian Wardani, Setiawan \& Supardi (2016) yang mengatakan bahwa pembelajaran inkuiri terbimbing memberikan pengaruh positif terhadap pemahaman konsep reaksi redoks pada peserta didik kelas X SMA Salatiga. Diperkuat oleh penelitian Purnamasari, Leny \& Saadi (2014) dyang menyatakan model inkuiri terbimbing juga dapat meningkatkan hasil belajar pada pembelajaran konsep larutan penyangga

\section{SIMPULAN}

Penggunaan model pembelajaran inkuiri terbimbing dapat meningkatkan aktivitas guru, aktivitas siswa dan mendapatkan respon yang positif dari peserta didik dalam pembelajaran tersebut. Model pembelajaran ini dapat meningkatkan pula pemahaman konsep peserta didik dan mengurangi miskonsepsi peserta didik pada materi reaksi redoks.

\section{DAFTAR RUJUKAN}

Aiken, L. R. (1985). Three Coefficients for Analyzing The Reliability and Validity of Ratings. Educational and Psychological Measurement, 131-142.

Barke, H. D. (2012). Two Ideas Of The Redox Reaction: Misconception And Their Challenge In Chemistry Education. ASEAN Journal Of Community Engagement, , 2 (2), 32-50.

Jauhariansyah, S. (2014). Pengembangan dan Penggunaan Tes Diagnostik Pilihan Ganda Dua Tingkat (two tier multiple choice) untuk Mengungkap Pemahaman Siswa Kelas X Pada Materi Konsep Redoks dan Larutan Elektrolit. Skripsi.

Kusumawati, I., Enawaty, E., \& Lestari, I. (2014). Miskonsepsi Siswa Kelas XII SMA Negeri 1 Sambas pada Materi Reaksi Reduksi Oksidasi. Jurnal Pendidikan dan Pembelajaran. 3 (6), 1-13.

Purnamasari, R., Leny, \& Saadi, P. (2014). Meningkatkan Hasil Belajar dengan Menggunakan Model Pembelajaran Inkuiri Terbimbing Berbantuan LKS pada Materi Larutan Penyangga Siswa Kelas XI IPA 2 SMA Negeri 12 Banjarmasin. Quantum, Jurnal Pendidikan Sains. 5(2), 13-19.

Rusmansyah. (2002). Penerapan Metode Latihan Berstruktur dalam Meningkatkan Pemahaman Siswa terhadap Konsep Persamaan Reaksi Kimia. Jurnal Pendidikan Nasional dan Kebudayaan, 35. , Jakarta: Departemen Pendidikan Nasional dan Kebudayaan.

Suparno, P. (2013). Miskonsepsi Dan Perubahan Konsep Dalam Penddikan Fisika. Jakarta: PT Gramedia Widiasarana.

Wardani, S., Setiawan, S., \& Supardi, K. I. (2016). Pengaruh Pembelajaran Inkuiri Terbimbing terhadap pemahaman konsep dan Oral Activities pada Materi Pokok Reaksi Oksidasi. Jurnal Inovasi Pendidikan Kimia 10 (2), 1743 - 1750.

Widiyowati, I. I. (2014). Hubungan Pemahaman Konsep Struktur Atom dan Sistem Periodik Unsur dengan Hasil Belajar Kimia Pokok Bahasan Ikatan Kimia. 3 (4), 99-116. 